\title{
PENGARUH MODEL PEMBELAJARAN NUMBERED HEAD TOGETHER BERORIENTASI TRI HITA KARANA TERHADAP HASIL BELAJAR PKN
}

\author{
${ }^{1}$ Putu Rismayani, ${ }^{2}$ Nyoman Dantes, ${ }^{3}$ Kadek Yudiana \\ ${ }^{1,3}$ Jurusan Pendidikan Dasar, Universitas Pendidikan Ganesha, Singaraja, Indonesia \\ 2Jurusan Teknologi dan Bimbingan Konseling, Universitas Pendidikan Ganesha, Singaraja, \\ Indonesia
}

e-mail: rissmayani27@gmail.com¹, dantes@undiksha.ac.id', kadek.yudiana@undiksha.ac.id ${ }^{2}$

\begin{abstract}
Abstrak
Penelitian ini bertujuan untuk mengetahui pengaruh model pembelajaran Numbered Head Together berorientasi Tri Hita Karana terhadap hasil belajar PKn siswa kelas V SD di Gugus $\mathrm{XV}$ Kecamatan Buleleng. Jenis penelitian ini adalah penelitian eksperimen semu dengan desain post test only control group design. Populasi penelitian ini adalah seluruh kelas V SD di Gugus XV Kecamatan Buleleng yang berjumlah 213 orang. Pemilihan sampel penelitian menggunakan teknik random sampling, dan yang dirandom adalah kelas sebagai intac grup, sehingga didapatkan siswa kelas V SD N 1 Anturan sebagai eksperimen dan kelas V SD 3 Kalibukbuk sebagai kontrol. Pengumpulan data dalam penelitian ini dilakukan dengan menggunakan metode tes. Data yang sudah dikumpulkan dianalisis dengan analisis statistik inferensial uji-t. Dari analisis data ditemukan bahwa terdapat nilai $t_{\text {hitung }}$ yaitu sebesar 27,382 lebih besar dari $t_{\text {tabel }}$ yang sebesar $2,021 \mathrm{Hal}$ ini berarti terdapat perbedaan yang signifikan hasil belajar PKn kelompok siswa yang mengikuti pembelajaran menggunakan model Numbered Head Together berorientasi Tri Hita Karana dan kelompok siswa yang mengikuti pembelajaran tidak menggunakan model Numbered Head Together berorientasi Tri Hita Karana terhadap hasil belajar PKn siswa kelas V SD di Gugus XV Kecamatan Buleleng. Selain itu berdasarkan analisis deskriptif diperoleh bahwa mean kelompok eksperimen lebih besar dari mean kelompok control $(25,46>14,38)$. Berdasarkan hasil analisis tersebut dapat disimpulkan bahwa terdapat pengaruh model pembelajaran NHT berorientasi Tri Hita Karana Terhadap Hasil Belajar PKn siswa Kelas V SD di Gugus XV Kecamatan Buleleng.
\end{abstract}

Kata-kata kunci: hasil belajar PKn, Numbered Head Together, Tri Hita Karana

\begin{abstract}
This research was aimed to know whether the effect of Numbered Head Together Learning model with oriented to Tri Hita Karana on PKn learning achievement. This research was a quasi experiment research with post-test only control group design. The population of this research was 213 students of grade V of Elementary School in Cluster XV Buleleng subdistric in the academic year of 2018/2019. By using a cluster random sampling technique, 54 students were selected as a sample in this study. Data were obtained through objective test for PKn learning achievement at the end of the research. The collected data were tested using descriptive analysis and independent t-test (with a several assumptions to be fulfilled). The result of data analysis showed that tobserved $=27.382$ which is greather than tcritical $=$ 2.021 in significance rate 5\%. It's means, there are significantly different between PKn learning achievement those students who were taught by using Numbered Head Together
\end{abstract}


with oriented to Tri Hita Karana and those who were taught by using conventional. Furthermore, based on descriptive analys, showed that the mean score of experimental class is higher than control class $(25.46>14.38)$.

Keywords: numbered head together, PKn learning achievment, tri hita karana

\section{PENDAHULUAN}

Pada jenjang pendidikan sekolah dasar, siswa dibelajarkan sejumlah mata pelajaran salah satunya PKn (Pendidikan Kewarganegaraan) Susanto (2013: 225) menyatakan, Pendidikan Kewarganegaraan adalah "mata pelajaran yang digunakan sebagai wahana untuk mengembangkan dan melestarikan nilai luhur dan moral yang berakar pada budaya bangsa Indonesia". Artinya selain memberikan materi berupa pengetahuan, smata pelajaran ini juga mengembangkan karakter siswa sesuai dengan budaya bangsa Indonesia. Pelaksanaan pembelajaran PKn haruslah dilaksanakan dalam suasana yang kondusif dalam arti kegiatan pembelajaran yang dilakukan bersifat aktif, efektif, dan menyenangkan. Untuk menciptakan suasana belajar yang kondusif, salah satu peran guru yang sangat penting yaitu memilih media yang akan digunakan dalam proses pembelajaran.

Pemilihan media yang tepat akan membantu tujuan pembelajaran dapat tercapai dengan optimal. Pembelajaran PKn di sekolah dasar dimaksudkan sebagai suatu proses belajar mengajar dalam rangka membantu peserta didik agar dapat belajar dengan baik dan membentuk manusia seutuhnya. Menurut Azyumardi (dalam Susanto, 2013: 226) Pendidikan kewarganegaraan adalah pendidikan yang mengkaji dan membahas tentang pemerintahan, hak dan kewajiban warga Negara serta proses demokrasi. Berdasarkan definisi di atas Pendidikan Kewarganegaraan dapat disimpulkan bahwa yang dimaksud dengan Pendidikan Kewarganegaraan adalah usaha sadar dan terencana dalam proses pembelajaran agar peserta didik secara aktif mengembangkanpotensi dirinya untuk memiliki kecerdasan, kecakapan, keterampilan serta kesadaran.

Pembelajaran PKn dikatakan berhasil apabila semua tujuan pembelajaran yang ditentukan dapat dicapai. Keberhasilan yang diperoleh siswa dapat dilihat dari hasil belajar siswa saat mengikuti proses pembelajaran. Hasil belajar sangat penting dalam pembelajaran untuk mengetahui apakah sudah ada perubahan pada diri siswa setelah melakukan pembelajaran baik secara pengetahuan, sikap, dan keterampilan. Hasil belajar merupakan suatu pencapaian yang diperoleh oleh siswa dalam bentuk pengetahuan, sikap, dan keterampilan setelah melakukan kegiatan belajar.

Susanto (2013: 5) menyatakan, hasil belajar merupakan "kemampuan yang diperoleh anak setelah melalui kegiatan belajar. karena belajar itu sendiri merupakan suatu proses dari seseorang yang berusaha memperoleh sesuatu bentuk perubahan prilaku yang relatif menetap". Jadi setelah melalui kegiatan belajar terdapat perubahan perilaku menjadi lebih baik sehingga bisa diterapkan dalam kehidupan sehari-hari. Untuk mengetahui apakah hasil belajar yang dicapai telah sesuai dengan tujuan yang dikehendaki dapat dilakukan dengan cara melakukan evaluasi. Sebagaimana yang dikemukakkan Sunal (dalam Susanto 2013:5) bahwa evaluasi merupakan "proses penggunaan informasi untuk membuat pertimbangan seberapa efektif suatu program telah memenuhi kebutuhan siswa". Jadi dengan Demikian pula yang terjadi di SD gugus XV Kecamatan Buleleng Kabupaten Buleleng. Berdasarkan hasil wawancara dengan Kepala Sekolah di SD gugus XV Kecamatan Buleleng Kabupaten Buleleng dan hasil studi dokumen menemukan rendahnya nilai yang diperoleh oleh siswa. 
Rata-rata nilai akhir semester I siswa kelas $\mathrm{V}$ pada mata pelajaran PKn dari 8 sekolah yang ada, 50\% lebih siswa yang memperoleh nilai di bawah kreteria ketuntasan minimal (KKM).

Adapun masalah yang dapat diidentifikasi sebagai faktor penyebab rendahnya hasil belajar siswa dalam mata pelajaranPKn di kelas V Sekolah Dasar gugus XV Kecamatan Bulelng Kabupaten Buleleng. Berdasarkan kegiatan Lapangan yakni observasi, di SD Gugus XV Kecamatan Buleleng Kabupaten Buleleng. Kenyataan tersebut belum sepenuhnya dipahami kalangan pendidikan, khususnya guru sekolah dasar. Namun kenyataannya pembelajaran PKn diajarkan dengan metode ceramah. Jadi pembelajaran lebih banyak bersifat satu arah. Siswa kurang bersemangat dalam belajar. Hal ini terlihat dari perilaku siswa ketika diberikan pertanyaan oleh guru, hanya beberapa siswa saja yang tunjuk tangan dan ingin menjawab, sementara siswa lain terlihat kurang memahami materi bahkan ada siswa yang justru mengobrol dengan temannya. Pada saat membuka pembelajaran guru jarang yang mengawali dengan doa besama, namun ketika masuk kelas langsung menuju inti pembelajaran dengan menjelaskan materi kepada siswa. Hal ini membuat hubungan siswa dengan Tuhan kurang dapat terbina, karena siswa tidak diajarkan pentingnya bersyukur kepada Tuhan dan berdoa untuk kelancaran pembelajaran yang akan dilaksanakan. Kegiatan sebelum memulai pembelajaran siswa dibiasakan mengadakan sembahyang bersama, namun dalam berlangsungnya persembahyangan ada beberapa siswa yang tidak serius masih bercanda dengan menoleh kanan kiri, serta memainkan tangannya, serta yang saya amati ketika melakukan observasi yakni saat melakukan pembersihan terlihat tidak adanya kerja sama beberapa siswa ada yang tidak ikut pembersihan sehingga menimbulkan perselisihan dan ada yang saling ejek nama orang tua. Saat kegitan istirahat ada beberapa siswa yang memilih untuk istirahat di areal taman sekolah namun siswa tersebut malah memetik daun-daun tanaman dan dijadikan bahan untuk bermain.

Siswa kurang dapat berinteraksi dengan baik saat pembelajaran, karena guru kurang memberikan kesempatan untuk bekerjasama dengan kelompok. Guru belum menerapkan model pembelajaran yang dapat membangkitkan semangat belajar siswa. Hal ini berujung pada hasil belajar PKn siswa yang rendah. Hal in dapat dilihat dari masih banyak siswa yang memperoleh nilai PKn di bawah KKM. Karena kurangnya interaksi antar sesama siswa dalam pembelajaran, membuat hubungan antar sesama siswa menjadi kurang harmonis. Siswa lebih cenderung individualistis. Ketika ada teman yang memerlukan bantuan teman lain, siswa kurang memiliki kepedulian untuk membantu. Selan itu, siswa juga kurang peduli dengan kebersihan lingkungan kelas. Ketika ada sampah-sampah kertas yang dibuat oleh siswa itu sendiri, siswa tidak membuangnnya di tempat sampah, namun ada yang menaruh dikolong bangku, atau membuangnya di lantai. Hal ini membuat suasana kelas menjadi kurang bersih.

Berdasarkan beberapa permasalahan yang telah dipaparkan, dengan menerapkan model pembelajaran yang inovatif serta memperhatikan keberagaman karakteristik yang dimiliki oleh siswa dalam proses pembelajaran akan memberikan pengaruh positif dalam pembelajaran PKn. Pada hakikanya mata pelajaran PKn di sekolah berfungsi mengembangkan sikap dan nilai moral, sedangkan tujuan pembelajarn PKn untuk memberikan pengalaman kepada siswa dalam merencanakan dan menerapkan sikap yang baik untuk membentuk moral dan watak yang baik pula contoh sikap moral yang dapat di kembangkan dengan model pembelajaran Numbered Head Together yaitu sikap kejujuran dan transparan. Pada saat ini telah berkembang berbagai modelpembelajaran inovatifuntuk diterapkan dalam proses pembelajaran PKn di SD. Salah satu model pembelajaran yang 
cocok diterapkan dalam pembelajaran PKn adalah model pembelajaran Numbered Head Together (NHT).

Model pembelajaran Numbered Head Together merupakan model pembelajaran yang dapat mengasah kemampuan bekerjasama antar siswa melalui kegiatan kelompok. Interaksi antar siswa juga dianggap berpengaruh dalam meningkatkan penguasaan akademik siswa, sehingga tujuan pembelajaran dapat tercapai.

Model pembelajaran ini memiliki ciri khas yakni guru hanya menunjuk seorang siswa mewakili kelompoknya tanpa memberitahu terlebih dahulu siapa yang akan mewakili kelompoknya sehingga hal ini menjamin keterlibatan semua siswa. cara ini upaya yang sangat baik untuk meningkatkan tanggung jawab individual dalam diskusi kelompok. NHT (Numbered head together) juga dikatakan sebagai model pembelajaran karena memiliki langkah-langkah (sintaks) yang digunakan oleh guru sebagai pedoman dalam merancang dan melaksanakan pembelajaran di kelas.

Model pembelajaraan NHT sangat baik diterapkan dalam pembelajaran PKn karena dapat membantu meningkatkan gairah siswa dalam belajar, selain itu dalam menggunakan model NHT ini siswa juga dituntut bisa membangun hubungan atau kerjasama dalam kelompok baik sesama teman dan guru dan dalam pembelajaran PKn mencakup makna siswa harus mengetahui hak dan kewajiban terutama pada lingkungan sekitar. Dengan demikian dalam penerapan model pembelajaran NHT semangat belajar siswa meningkat, sehingga mempengaruhi hasil belajar siswa. Akan tetapi model pembelajaran saja tidak cukup untuk membangun kepedulian siswa dalam membina hubungan yang baik dengan Tuhan, dengan sesama manusia dan dengan lingkungan sekitar. Model Pembelajaran NHT perlu berorientasi dengan Tri Hita Karana.

Wiana, (2007: 5) menyatakan "Tri Hita Karana berasal dari bahasa sansekerta, istilah Tri Hita Karana berasal dari kata Tri yang artinya tiga (3), Hita artinya bahagia dan Karana Penyebab. Dengan demikian Tri Hita Karana merupakan tiga penyebab kebahagiaan". Nama Tri Hita Karana inilah yang di jadikan judul untuk menyebutkan ajaran yang mengajarkan agar manusia mengupayakan hubungan harmonis dengan Tuhan, dengan sesama manusia dan dengan alam lingkungannya. Berdasarkan pernyataan tersebut, sebagai manusia, siswa dituntut untuk dapat menciptakan hubungan yang harmonis dengan Tuhan, dengan sesama manusia dan dengan lingkungan sekitar, sehingga tercipta keharmonisan yang seimbang.

Konsep Tri Hita Karana ini sangat berhubungan dengan mata pelajaran PKn, dimana pada mata pelajaran PKn siswa diajarkan untuk menjadi warga negara yang baik, taat terhadap perintahnya-Nya, serta menjauhi larangan-Nya kemudian pada pembelajaan PKn juga siswa akan belajar mengenai kebebasan tiap warga negara dalam memeluk agamanya masing-masing, sehingga setiap masyarakat dapat saling menghormati meskipun memeluk keyakinan/agama yang berbeda. Selain itu, saat memulai pembelajaran perlu dibiasakan berdoa untuk kelancaran pembelajaran dan mengucap syukur kepada Tuhan atas kesempatan yang diberikan sehingga dapat mengikuti pembelajaran. Hal ini tercermin dalam ajaran Tri Hita Karana, yaitu Parhyangan, yang artinya hubungan yang harmonis antara manusia dengan Tuhan. Selain itu perlu juga ditanamkan hubungan yang harmonis antar sesama manusia yang tercermin dalam ajaran Tri Hita Karana yaitu Pawongan. Dalam ajaran pawongan siswa diajarkan untuk saling menghormati, saling tolong-menolong antar sesama manusia. Siswa juga diajarkan untuk saling bekerja sama dengan sesama siswa yang dapat diwujudkan dalam diskusi saat pembelajaran berlangsung untuk membina hubungan dan interaksi yang baik antar sesama siswa da antara siswa dengan guru. 
Begitu pula pada bagian Palemahan, yang artinya hubungan yang harmonis antara manusia dengan lingkungannya. Pada bagian Palemahan ini, sebagai manusia yang beradab, diharapkan untuk dapat mencintai lingkungan dan menjaga serta merawat alam agar alam dan lingkungan tempat tinggal kita asri dan lestari sehingga kita sebagai manusia dapat tinggal dengan nyaman di lingkungan kita. Hal ini pula yang ditanamkan pada pembelajaran PKn, sehingga ajaran dalam Tri Hita Karana memiliki pengaruh besar dalam tercapainya tujuan pembelajaran PKn.

Dengan model pembelajaran NHT berorientasi Tri Hita Karana, tersebut dalam pembelajaran maka selain membangkitkan minat belajar siswa, juga siswa akan mengamalkan makna dari pedoman hidup umat Hindu di Bali sehingga pembelajaran menjadi lebih baik membentuk karakter siswa yang lebih baik. Hal ini juga nantinya akan berujung pada hasil belajar siswa yang lebih tinggi.

Berdasarkan paparan tersebut, sehingga dalam penelitian ini mengambil judul tentang "Pengaruh Model Pembelajaran Numbered Head Together (NHT) Berorientasi Tri Hita Karana terhadap Hasil Belajar PKn siswa kelas V SD Gugus XV Kecamatan Buleleng Kabupaten Buleleng".

Adapun tujuan yang ingin dicapai pada penelitian ini adalah Untuk mengetahui kualitas hasil belajar PKn siswa kelas V di SD Gugus XV kecamatan Buleleng Kabupaten Buleleng.Untuk mengetahui pengaruh model pembelajaran Numbered Head Together (NHT) berorientasi Tri Hita Karana terhadap hasil belajar Pkn siswa kelas V di SD Gugus XV kecamatan Buleleng Kabupaten Buleleng.

\section{METODE}

Jenis penelitian ini adalah penelitian ekperimen semu dengan desain penelitian posttest only control group. Namun pada penelitian eksperimen ini harus dapat memperlihatkan adanya perubahan variabel terikat yang mengakibatkan dari adanya perlakuan variabel bebas yang ditentukan oleh faktor-faktor lain seperti validitas internal. Validitas internal adalah pengontrolan peneliti terhadap variabel-variabel yang dapat mempengaruhi hasil dari kelompok eksperimen (Setyosari, 2012). Adapun beberapa ancaman yang dapat mempengaruhi validitas internal yaitu hilangnya subjek (mortality), kematangan, implementasi, dan instrumentasi (Setyosari, 2012). Pengontrolan subjek, berkaitan pada intlektual dan umur setiap individu yang dipilih sebagai sampel, dari hal tersebut menimbulkan dampak antara kelas kontrol dan eksperimen layak untuk di bandingkan. Pengontrolan hilang subjek (morality) pada saat proses pembelajaran berlangsung. Pada pengontrolan implentasi adalah ketidak sesuai instrumen yang diterapkan tidak sesuai dengan yang sudah dirancang. Instrumen yang dimaksud adalah RPP dan media. Untuk dapat mengatasi semua faktor yang sudah dijabarkan yaitu melakukan uji kesetaraan dan memilih sampel yang setara, setiap pelaksanaan perlu dilakakukanya absensi dan pengaturan waktu di kelas kontrol dan eksperimen, serta melakukan penyeragaman indikator pada kelas eksperimen dan kontrol.

Pada penelitian ini validitas eksternal perlu pula diperhatikan, validitas eksternal adalah harapan bahwa hasil-hasil penelitian dapat diaplikasikan pada situasi atau kelompok yang lebih banyak dan waktu serta lokasi lebih luas. Dengan demikian, adapun faktor yang mempengaruhinya pada penelitian ini yaitu efek seleksi terhadap sampel dan efek prosedur eksperimen yaitu (a) Efek seleksi terhadap sampel berarti pengambilan sampel dalam jenis penelitian haruslah mewakili populasi sehingga tidak terjadi generalisasi yang dihasilkan berlaku bagi sampel dan populasi lebih luas dan (b) Efek prosedur eksperimen, yaitu sampel yang menyadari bahwa dirinya sedang dieksperimen menyebabkan generalisasi 
yang diperoleh bisa tdak berlaku bagi populasi. Hal ini terjadi karena adanya perbedaan pengalaman antar anggota sampel dengan populasi sehingga perlu dilakukan kontrol terhadap pengaruh prosedur eksperimen. Populasi adalah keseluruhan subjek penelitian (suharsimi Arikunto, 2002). Populasi dalam penelitian ini adalah seluruh siswa kelas V SD Gugus XV Kecamatan Buleleng Kabupaten Buleleng.

Banyaknya anggota populasi dalam penelitian ini adalah 213 orang siswa yang tersebar ke dalam delapan Sekolah yang terdiri dari 8 kelas seperti pada tabel 1 berikut.

Tabel 1. Sebaran Anggota Populasi

\begin{tabular}{lll}
\hline No. & Sumber Populasi & Jumlah Siswa \\
1 & SD N 1 Kalibukbuk & 21 \\
2 & SD N 2 Kalibukbuk & 24 \\
3 & SD N 3 Kalibukbuk & 21 \\
4 & SD N 4 Kalibukbuk & 37 \\
5 & SD N 1 Anturan & 35 \\
6 & SD N 2 Anturan & 23 \\
7 & SD N 3 Anturan & 31 \\
8 & SD Triamerta & 21 \\
\hline
\end{tabular}

Dari delapan sekolah populasi dipilih 2 sampel yang akan dijadikan sampel penelitian yaitu SD N 1 Anturan dan SD N 3 Kalibubuk Sebelum sampel dipilih maka dilakukan terlebih dahulu uji kesetaraan terhadap sampel yang akan digunakan. Adapun hasil uji kesetaraannya yang dihitung dengan uji tindependent diperoleh SD N 1 Anturan dan SD N 3 Kalibubuk memiliki kemampuan yang setara. Metode yang dipilih untuk mengumpulkan data hasil belajar PKn pada siswa kelas V semester II di SD Gugus XV Kecamatan Buleleng adalah pemberian tes pada kelas eksperimen dan kelas kontrol. Jenis tes yang digunakan adalah tes pilihan ganda. Tes hasil belajar PKn pada penelitian ini dibuat untuk mengkur kemampuan siswa dalam belajar PKn pada seluruh sampel. Tes ini berupa soal pilihan ganda (multiple choise) yang terdiri dari 40 soal yang dibuat berdasarkan indikator materi PKn kelas V SD.

Sebelum instrument digunakan, terlebih dahulu dilakukan uji pakar untuk melihat kualitas isi dari instrument, kemudian instrument di ujikan ke beberapa orang siswa untuk mementukan validitas tiap butir soal yang akan diuji dengan menggunakan korelasi Point Biserial, uji reliabilitas menggunakan KR-21, uji tingkat kesukaran, dan diuji daya bedanya. Berdasarkan hasil uji coba intrumen, diperoleh dari 40 soal yang diujikan terdapat 30 soal yang valid, dan akan digunakan sebagai instrument posttest. Data yang diperoleh dalam penelitian ini adalah hasil belajar PKn siswa yang merupakan data kuantitatif dan dianalisis dengan statistik desktritif dan statistik inferensial. Statistik inferensial adalah semua penyelidikan yang didasarkan atas data statistik beserta petunjuk-petunjuk tentang ketelitian dan kemantapan dari keputusan yang diambil berdasarkan teori probabilitas. Analisis deskriptif dilakukan untuk mengetahui tinggi rendahnya kualitas dari hasil belajar siswa. Untuk menentukan tinggi atau rendahnya hasil belajar PKn digunakan kriteria rata-rata ideal dan standar deviasi ideal. Pendeskripsian data untuk hasil belajar siswa dilakukan berdasarkan tendensi data, meliputi mean, median, modus, standar deviasi, varians. Kualifikasi dideskripsikan atas dasar rata-rata ideal (Mi) dan simpangan baku ideal (SDi). Statistic inferensial yang digunakan berupa uji prasyarat yaitu normalitas menggunakan uji Kolmogorov-Smirnov dan Uji Homogenitas menggunakan uji Levene sedangkan pengujian hipotesis menggunakan uji- $t$ satu ekor (ekor kanan) dengan taraf signifikan $5 \%$..

HASIL DAN PEMBAHASAN 
Data hasil belajar PKn yang diperoleh melalui post-test terhadap 35 orang siswa menunjukkan bahwa skor tertinggi adalah 28 dan skor terendah adalah 21 . Data hasil belajar PKn kelompok eksperimen dari hasil perhitungan maka ditetapkan banyak kelas adalah 6 dan panjang kelas adalah 1. Selanjut data hasil belajar PKn akan di konversika skala penilaian sehingga diperoleh bahwa skor rata-rata hasil belajar siswa kelompok eksperimen, dengan $M=25,46$ tergolong kriteria "Sangat baik". Untuk gambaran lebih lengkap dan jelas mengenai distribusi frekuensi skor hasil belajar PKn siswa kelas V SD N 1 Anturan yang mengikuti model pembelajaran NHT berorientasi Tri Hita Karana dapat dilihat pada histogram 1.

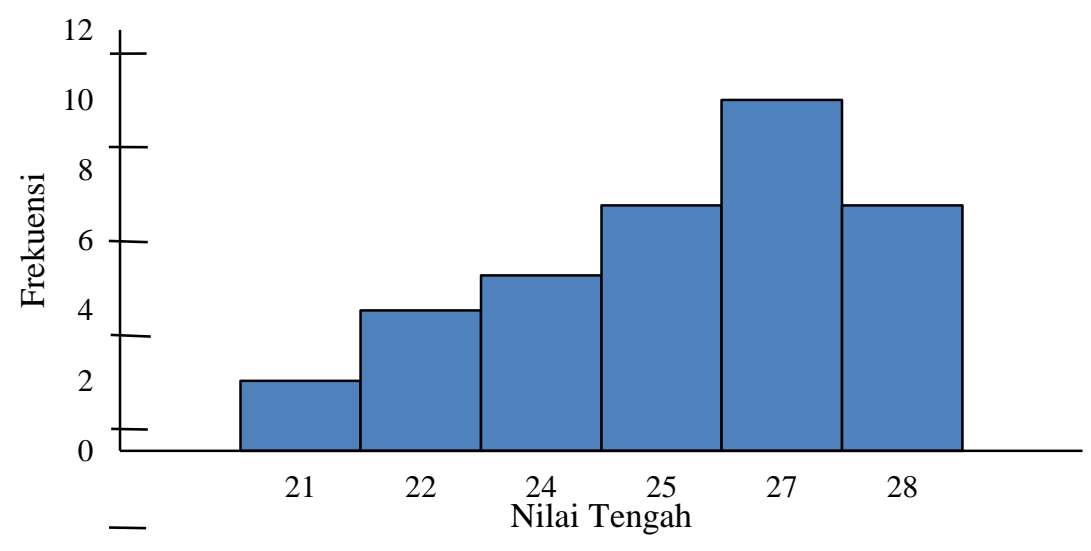

Gambar 1. Histogram Hasil Belajar PKn Kelompok Eksperimen

Deskripsi data hasil belajar PKn pada kelompok kontrol yakni data hasil belajar PKn yang diperoleh melalui post-test terhadap 21 orang siswa menunjukkan bahwa skor tertinggi adalah 18 dan skor terendah adalah 12. Berdasarkan hasil perhitungan maka ditetapkan banyak kelas adalah 5 dan panjang kelas adalah 1. Selanjutnya data pos-test hasil belajar PKn akan di konversikan ke skala penilaian sehingga diperoleh bahwa skor rata-rata hasil belajar siswa kelompok kontrol, dengan $\mathrm{M}=14,38$ tergolong kriteria "sedang". Untuk gambaran lebih lengkap dan jelas mengenai distribusi frekuensi skor hasil belajar PKn siswa kelas V SD N 1 Anturan yang tidak mengikuti model pembelajaran NHT berorientasi Tri Hita Karana dapat dilihat pada histogram 2.

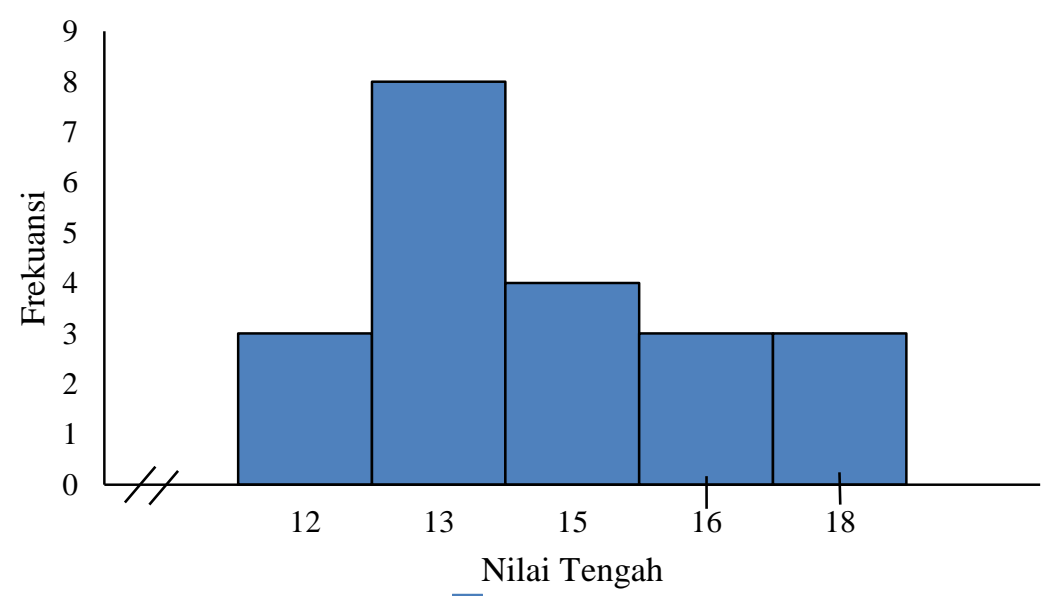

Gambar 2. Histogram Hasil Belajar PKn Kelompok Kontrol 
Sebelum dilakukan pengujian hipotesisi dilakukan pengujian asumsi berupa uji normalitas sebaran data dan uji homogen varians. Uji normalitas data dilakukan terhadap data hasil belajar PKn kelompok eksperimen dan kontrol. Berdasarkan hasil perhitungan dengan menggunakan rumus Kolmogorov Smirnov diperoleh data hasil post-test kelompok eksperimen dan kontrol berdistribusi normal. Lebih lengkapnya dapat disajikan hasil uji normalitas sebaran data hasil belajar PKn kelompok eksperimen dan kontrol pada Tabel 2.

Tabel 2. Rangkuman Hasil Uji Normalitas Sebaran Data

\begin{tabular}{lllr}
\hline No & Kelompok Data Hasil Belajar PKn & Dhitung & Dtabel Status \\
1 & Eksperimen & 0,111 & 0,230 Normal \\
2 & Kontrol 0,279 & 0,294 & Normal \\
\hline
\end{tabular}

Uji Homogenitas dilakukan untuk mencari tingkat kehomogenan secara dua pihak yang diambil dari kelompok-kelompok terpisah dari satu populasi yaitu kelompok kontrol dan kelompok eksperimen. Uji yang digunakan adalah Uji Levene dengan kriteria data homogen jika $W<F_{\text {tabel }}$ yaitu $1,49<4,04$. Berdasarkan hasil perhitungan diketahui $W$ hasil kelompok eksperimen dan kontrol adalah 1,49 sedangkan dkpembilang $=2-1=1$ dan dkpenyebut $=56$ $2=54$, dan taraf signifikansi $5 \%$, maka diperoleh nilai $F_{\text {tabel }}=4,08$. Hal ini berarti, varian data hasil belajar PKn kelompok eksperimen dan kontrol adalah homogen.

Pada penelitian ini, pengujian hipotesis menggunakan uji-t dengan kriteria pengujian adalah $\mathrm{H} 0 t_{\text {hitung }}>t_{\text {tabel }}$ dimana $t_{\text {tabel }}=t(1-a)(d k)$ dengan derajat kebebasan $d k=(n 1+n 2-2)$ dan $\alpha=5 \%$. Rangkuman hasil analisis uji-t ditampilkan pada Tabel 3.

Tabel 3. Hasil Uji-t

\begin{tabular}{lllll}
\hline Kelompok & $\mathrm{N}$ & $\mathrm{Db}$ & Mean & $\mathrm{t}_{\text {hitung }} \mathrm{t}_{\text {tabel }}$ \\
Eksperimen & 35 & 54 & 25,46 & $27,3822,021$ \\
Kontrol21 & & 14,38 & & \\
\hline
\end{tabular}

Berdasarkan tabel analisis di atas, dapat diketahuithitung $=27,382$ dan ttabel $=$ 2,021 untuk $\mathrm{dk}=54$ pada taraf signifikansi $5 \%$. Berdasarkan kriteria pengujian, karena thitung > ttabel maka $\mathrm{HO}$ ditolak dan $\mathrm{H} 1$ diterima. Artinya, terdapat pengaruh model pembelajaran NHT berorientasi Tri Hita Karana terhadap hasil belajar PKn pada siswa kelas V semester II di SD Gugus XV Kecamatan Buleleng.

Berdasarkankan hasil uji hipotesis, diperoleh hasil yaitu terdapat pengaruh model pembelajaran Numbered Head Together (NHT) berorientasi Tri Hita Karana terhadap hasil belajar PKn siswa Kelas V di SD Gugus XV Kecamatan Buleleng Kabupaten Buleleng. Diterimanya hasil uji hipotesis tersebut di karenakan pada model pembelajaran NHT setiap anggota kelompok bertanggung jawab atas tugas kelompoknya. Selain itu siswa saling memberi dan menerima masukan satu samayang lainnya guna memperoleh nilai yang maksimal sehingga termotivasi untuk belajar. Model pembelajaran NHT juga mengedepankan aktifitas siswa dalam mencari, mengolah, dan melaporkan informasi untuk menjawab tugas yang diberikan oleh guru. Dengan adanya aktifitas siswa yang aktif, akan memberikan pembelajaran yang bermakna pada siswa sehingga mempengaruhi hasil belajar PKn siswa. Hal ini sejalan dengan pendapat Fathurrohman (2015:82) bahwa model NHT adalah suatu model pembelajaran yang lebih mengedapankan aktifitas siswa dalam mencari, mengolah, dan melaporkan informasi dari berbagai sumber yang akhirnya di presentasikan di depan kelas. Pendapat tersebut didukung oleh pendapat (Shoihimin, 2014: 108) yang menyatakan bahwa NHT merupakan suatu model pembelajaran berkelompok yang setiap anggota kelompoknya bertaggung jawab atas tugas kelompoknya, sehingga 
tidak ada pemisahan antara siswa yang satu dan siswa yang lain dalm satu kelompok untuk saling memberi dan menerima antara satu dengan yang lainnya.

Keberhasilan penerapan model pembelajaran NHT tidak lepas dari tujuan model pembelajaran NHT yaitu memberikan kesempatan kepada siswa untuk saling berbagi gagasan dan mempertimbangkan jawaban yang paling tepat (Huda, 2014:203). Kemudian Isjoni (2007:75) juga menyatakan bahwa tujuan penting dari pembelajaran kooperatif adalah untuk mengajarkan kepada siswa keterampilan kerja sama dan kolaborasi. Menurut (Shoimin, 2014: 108-109) model pembelajaran Numbered Head Together (NHT) mempunyai kelebihan dalam penerapannya. Kelebihan tersebut yaitu sebagai berikut; (1) setiap murid menjadi siap, (2) dapat melakukan diskusi dengan sungguh-sungguh, (3) murid yang pandai dapat mengajari murid yang kurang pandai, (4) terjadi interaksi secara intens antar siswa dalam menjawab soal, (5) tidak ada murid yang mendominasi dalam kelompok karena ada nomor yang membatasi.

Pembelajaran PKn, berkaitan dengan sikap yang dimiliki siswa. selain model pembelajarn NHT yang mengaktifkan siswa selama pembelajaran, diperlukan pula penanaman sikap untuk menyempurnakan hasil belajar PKn siswa. oleh karena itu model pembelajaran NHT perlu berorientasi Tri Hita Karana. Tri Hita Karana merupakan tiga penyebab kebahagiaan. Bagian-bagian Tri Hita Karana menurut Wiana (2007:8) yaitu, Parhyangan, Pawongan, dan Palemahan. Parhyangan adalah hubungan yang harmonis antara manusia dengan Tuhan yang Maha Esa. Penerapan Parhyangan dalam pembelajaran dapat dilihat pada saat memulai kegiatan pembelajaran diawali dengan doa bersama. Hal tersebut dimaksudkan untuk mengucapkan rasa syukur kepada tuhan karena dapat mengikuti proses pembelajaran.

Bagian kedua dari Tri Hita Karanaadalah Pawongan. Pawongan merupakan hubungan harmonis antara manusia dengan manusia. Dalam tahapan model NHT, penerapan Pawongan dapat dilihat pada tahap pembentukan dan diskusi kelompok yang dilakukan oleh siswa. Pada tahapan ini siswa dituntut bisa saling berinteraksi serta mengemukakan pendapat dengan anggota kelompok, namun perlu adanya sikap saling menghargai pendapat teman pada kelompok untuk dapat membina hubungan yang harmonis antara manusia dengan manusia.

Bagian ketiga dari Tri Hita Karana Palemahan. Palemahan adalah hubungan yang harmonis antara manusia dengan lingkungannya. Pada tahapan model pembelajaran NHT, palemahan dapat dilihat pada kegiatan siswa ketika belajar di luar kelas dengan syarat tidak merusak lingkungan. Hal tersebut menunjukkan bahwa siswa diajarkan untuk dapat mencintai lingkungan, sehingga tercipta hubungan yag harmonis antara manusia dsengan lingkungan.

Hal ini berbeda dengan siswa yang dibelajarkan dengan model konvensional pada kelas kontrol. Pembelajaran mencirikan pembelajaran yang berpusat pada guru. Secara teoritis, pembelajaran yang menggunakan model konvensional adalah pembelajaran tradisional atau disebut juga dengan metode ceramah, karena sejak dulu metode ini telah dipergunakan sebagai alat komunikasi lisan antara guru dengan anak didik dalam proses belajar dan mengajar. Dalam hal ini, terlihat bahwa pembelajaran kurang maksimal dalam meningkatkan hasil belajar siswa.

Dengan demikian hasil penelitian ini membuktikan bahwa model pembelajaran model pembelajaran NHT berorientasi Tri Hita Karana memberikan pengaruh terhadap hasil belajar PKn siswa. Tentu saja dalam hal ini hasil belajar siswa meningkat. Hal ini dapat dilihat dari pembelajaran lebih banyak menekankan siswa aktif di dalam kelompoknya sedangkan guru hanya bertugas sebagai fasilitator dan motivator dalam pembelajaran. 
Keberhasilan model pembelajaran NHT berorientasi Tri Hita Karana didukung oleh hasil penelitian yang dilakukan Apriliani, (2017) yang berjudul "Pengaruh Model Pembelajaran Kooperatif Tipe Numbered Head Togethe r(NHT) terhadap Hasil Belajar PKn Kelas IV SD Negeri 33 Keraton". Hasil penelitiannya menunjukkan bahwa, terdapat pengaruh yang signifikan pada penerapan pembelajaran kooperatif tipe Numbered Head Together hasil belajar konitif siswa pada mata pelajaran PKn.

Berdasarkan uraian di atas, menunjukkan bahwa diperlukannya model pembelajaran NHT berorintasi Tri Hita Karana untuk meningkatkan hasi belajar PKn Siswa Kelas V SD di Gugus XV Kecamatan Buleleng.

\section{SIMPULAN}

Mengacu pada hal yang terjadi di lapangan, diperoleh sebuah permasalahan pokok yaitu, masih rendahnya hasil belajar PKn pada siswa kelas V Gugus XV Kecamatan Buleleng. Solusi yang dipilih untuk mengatasi masalah ini adalah dibelajarkannya model pembelajaran NHT berorientasi tri hita karana sehingga penelitian ini bertujuan untuk mengetahui perbedaan yang terjadi setelah siswa diberikan perlakuan model pembelajaran NHT berorientasi tri hita karana dan siswa yang dibelajarkan menggunakan pembelajaran konvensional. Adapun manfaat penelitian secara teoritis adalah sebagai sumber penelitian berikutnya dan menambah wawasan serta bermanfaat untuk memperkaya ilmu tentang pendidikan kewarganegaran, dan dapat dijadikan sebagai pedoman khususnya tentang model pembelajaran Numbered Head Together (NHT) yang akan digunakan dalam pembelajaran PKn, sedangkan manfaat secara praktis adalah penelitian ini dapat dijadikan sebagai pengalaman belajar, acuan dan pedoman dalam memilih dan mengenbangkan model pembelajaran yang inovatif bagi siswa, guru, kepala sekolah, dan peneliti lain.

Hasil belajar PKn merupakan suatu tingkat keberhasilan yang diperoleh anak setelah menjalani proses belajar melalui kegiatan belajar mata pelajaran PKn. Pada hakikatnya mata pelajaran PKn dijadikan untuk membentuk manusia agar mampu mengembangkan nilai luhur dan moral yang berlandaskan Pancasila, Undang-undang dan norma-norma yang berlaku di masyarakat. Model pembelajaran NHT, adalah sebuah model pembelajaran yang mengedepankan aktivitas siswa dalam mencari, mengolah, dan melaporkan informasi dari berbagai sumber yang akhirnya dipresentasikan di depan kelas, yang dirancang untuk mempengaruhi pola interaksi siswa dan sebagai alternatif terhadap struktur kelas tradisional, sedangkan tri hita karana mengajarkan agar manusia mengupayakan hubungan harmonis dengan Tuhan, dengan sesama manusia dan dengan alam lingkungannya diterapkannya tri hita karana dalam proses pembelajaran agar tercapainya harmoni dan juga kebersamaan dalam lingkungan sekolah, disamping harmoni dan kebersamaan pihak sekolah dengan lingkungan sekitarnya. Penelitian dilakukan termasuk ke dalam kuasi eksperimen menggunakan post-test only control group design dengan sampel penelitian yang ditentukan secara random. Hasil belajar PKn kelompok sampel diperoleh melalui tes pilihan ganda, yang telah di uji kelayakannya. Pengujian analisis data menggunakan uji-t menggunakan taraf signifikansi $5 \%$ dengan hasil yaitu, terdapat perbedaan hasil belajar PKn antara kelompok siswa yang dibelajarkan model pembelajaran $\mathrm{NHT}$ berorientasi tri hita karanadan kelompok siswa yang dibelajarkan pembelajaran konvensional pada siswa kelas $\mathrm{V}$ semester II di SD Gugus XV Kecamatan Buleleng.

Berdasarkan pada hasil analisis dan pembahasan dinyatakan bahwa kualitas hasil belajar PKn di kategorikan bagus dilihat rata-rata skor hasil belajar kelompok eksperimen lebih tinggi dari pada kelompok kontrol, jadi dapat disimpulkan bahwa terdapat pengaruh 
model pembelajaran NHT berorientasi Tri Hita Karana terhadap hasil belajar PKn siswa kelas V semester II di SD Gugus XV Kecamatan Buleleng.

Berdasarkan hasil penelitian pengalaman yang diperoleh selama melakukan penelitian, disarankan; 1) kepada guru untuk menggunakan model pembelajaran NHTpada pembelajaran PKn maupun mata pelajaran lainnya. Selain itu guru lebih memperhatikan pembagian kelompok agar terciptanya kelompok yang heterogen dan memperhatikan variasi tempat serta media yang terlibat pada penyelidikan agar tidak terjadi kebosanan, 2) kepada kepala sekolah untuk ikut memberikan dukungan dan motivasi pada guru-guru untuk menerapkan model NHT dalam pembelajaran di kelas, dan 3) kepada peneliti lain, untuk mengembangkan model pembelajaran NHT, sehingga akan menambah referensi dalam kajian-kajian ilmiah dan pengetahuan pada bidang pendidikan khususnya pengetahuan tentang model-model pembelajaran.

\section{DAFTAR RUJUKAN}

Apriliani, Vivi. 2017. "Pengaruh Model Pembelajaran Kooperatif Tipe Number Head Together (NHT) terhadap Hasil Belajar PKn Kelas IV SD Negeri 33 Negerikaton". Skripsi. Tersedia pada http://jurnal.fkip.unila.ac.id/index.php/pgsd/article/view/13289. Diakses pada 22 Januari 2019.

Arikunto, S. (2002). Prosedur Penelitian Suatu Pendekatan Praktek. Jakarta: Asdi Mahasatya.

Wiana, Ketut. 2007. Cara Belajar Agama Hindu yang Baik. Denpasar: Yayasan Dharma Narada.

Huda, Miftahul.2014.CooperatifLearning.PustakaPelajar.Yogyakarta.

Isjoni. 2007. cooperative Learning efektivitas Pembelajaran Kelompok Bandung: Alfabeta

Shoimin, Aris. 2014. 68 Model Pembelajaran INOVATIF dalam kurikulum 2013 Yogyakarta: Ar- Ruzz Media.

Susanto, Ahmad. 2013. Teori Belajar dan Pembelajaran di Sekolah Dasar. Jakarta: Kencana Prenadamedia Group.

Setyosari, P. 2012. Metode Penelitian Pendidikan dan Pengembagan. Jakarta: Prenada Media Group. 